\title{
Damage Remedies and Institutional Reform: The Right to Refuse Treatment
}

by Barry R. Furrow, J.D.

$\mathrm{T}$ he articulation by a court of a new constitutional norm serves a valuable function: the right, as elaborated by judicial opinion, provides a standard for critically evaluating current social practices. ' The "right to refuse treatment," that "newly created constitutional right of personal autonomy," draws attention to the problems of institutionalized mental patients and their desires to make their own decisions to accept or reject drug therapies, particularly where severe side effects are involved. The enunciation of the right to refuse treatment, with its hard-edged overtones, forces us to look at the tension created by the conflict between institutional attempts to treat these patients, the sometimes antithetical desire of those within the institution to control them without regard for treatment impact, and the patient's desire to retain whatever control is left to him in such setrings. ${ }^{3}$

The right to refuse treatment - like its common law analogue in tort, informed consent doctrine - draws its roots from concepts of personal autonomy that pervade both tort doctrine and constitutional law. ${ }^{4}$ The right remains poorly articulated as to its origins and reach. It is the remedy, how. ever, for deprivations of personal autonomy that has drawn the attention of critics. This is proper, for it is the combination of the right and the remedy that gives meaning to the public value at stake. An effective remedy places the right firmly in place in our hierarchy of values; an ineffective remedy, or none at all, relegates the right to an abstraction or to an admonition without teeth.

Mr. Furrow is an Associate Professor (Visiting) at the University of Detroit School of Law, and a Lecturer in the School of Public Health at the University of Michigan in Ann Arbor

152 Lau. Medicine \& Health Care
The utility of a damage award, the assessing of monetary costs against named defendants in litigation which is based on the right to refuse treatment, has been little discussed in the literature. For example, no damages were assessed by the Court of Appeals for the First Circuit in Rogers $v$. Okin, for doctrinal reasons related to official immunities; damages have not been part of the remedial structure thus far considered by the federal courts. As will be discussed in this article, as the right to refuse treatment continues to

The right to refuse treatment draws its roots from concepts of personal autonomy and seems based in the constitutional right of privacy.

develop, official immunities are less likely to be available as a defense in institutional litigation. It is therefore essential to understand the law of damages, and their limits and utility in institutional reform and patient protection, so that proper remedies can be applied. I propose to use the Rogers decisions as a starting point for a preliminary assessment of the legal and instrumental role of damage remedies in cases that involve the right to refuse medication.

\section{Linking the Right to the Remedy}

Constitutional damage remedies are complicated for two reasons. First, the availability of damages depends upon a finding of a lack of official immunity. The immunity doctrine reflects judcial uncertainty about the relative merits of damages and the potential risk of overkill in imposing damages on public officials. Second, several types of

damages must be considered, requiring different quanta of proof by plaintiffs, depending in part upon the nature of the constitutional principle and its relationship to its common law antecedents. Our inquiry must therefore be- gin with the discussion in Rogers of the constitutional foundations of the right to refuse treatment.

The constitutional right of privacy seems to provide the most recognizable basis for the right to refuse treatment. The plaintiffs in Rogers contended that "the forcible injection without informed consent of psychotropic medication violates a patient's constitutional right of privacy." The notion of the patient as autonomous decisionmaker was crucial to the District Court and to the Court of Appeals. The District Court quoted from Saikeuicz:

The constitutional right to privacy... is an expression of the sanctity of individual free choice of life. The value of life as so perceived is lessened not by a decision to refuse treatment, but by the failure to allow a competent human being the right of choice.?

The Court of Appeals relied upon notions of personal autonomy and the right of a person "to decide for himself " whether to accept treatment with psychotropic drugs. ${ }^{8}$ The court further stated that although "the precise textual source in the Constitution ... is unclear ... a source in the Due Process Clause of the Fourteenth Amendment for the protection of this interest exists, most likely as part of the penumbral right to privacy, bodily integrity, or personal security." The common law analogues to this right can readily be found in the torts of invasion of privacy, battery, false imprisonment, and other "dignitary" torts. ${ }^{10}$

The source of the constitutional right articulated in Rogers and other "right to refuse treatment" cases is important, because of the linkage between that source and the available remedies.

In Carey v. Piphus, ${ }^{11}$ in 1978, the United States Supreme Court reaffirmed the principle that compensa- 
tion for actual injuries, based on the private law model, should be the goal of damage awards in constitutional tort cases, ${ }^{12}$ although that need not al. ways be the complete solution. ${ }^{13}$ The Court in Carey suggested that the interests protected by a particular constitutional right must first be identified, and then a determination made as to whether those interests are protected by common law. ${ }^{14}$ If they are, the normal range of tort damage remedies which corresponds to the constitutional right in issue is directly applicable to the action. ${ }^{15}$ If these interests are not so protected, "the rules governing compensation for injuries caused by the deprivation of constitutional rights should be tailored to the interests protected by the particular right in question - just as the common law rules of damages themselves were defined by the interests protected in the various branches of tort law." 16 Proof of actual injury is normally required for damages to be awarded at common law. However, "the interests protected by a particular constitutional right may not also be protected by an analogous branch of the common law of torts." 17 Where the fit between the law of torts and the constitutional right is not perfect, the Court prescribed a modification of "common law rules of damages to provide fair compensation for injuries caused by the deprivation of a constitutional right." 18 The Court thereby left open the possibility that proof of tangible injury might not be required in certain situations. ${ }^{19}$

The existence of a damage rem. edy will often turn upon whether the defendant knew or should have known that his conduct would violate the plaintiff's constitutional right.

We start then with the following proposition: the range of available damages is dependent upon the common law tort most similar to the constitutional right. If no direct connection is possible, then the damage remedy should be tailored to the particular right violated. The possibility of awarding presumed damages, even in the absence of proof of actual harm, should be considered.

Our next step is a detour into im- munity doctrine. A finding of immunity may be in effect a judicial recognition that damages would be unfair or ineffective in deterring official misconduct in a particular context.

\section{Official Immunities}

Official immunities operate to limit the reach of a constitutional right. The defendant's state of mind at the time of the act and the later imposition of damages are interdependent: the existence of a damage remedy will often turn upon whether the defendant knew or should have known that his conduct would violate the plaintiff's constitutional right. Even though a constitutional violation has been found, the defendant can escape liability, but not necessarily equitable relief, by showing that he acted in good faith and without malicious intent to deprive the plaintiff of a constitutional right. ${ }^{20}$ Good faith is an affirmative defense, and recent Supreme Court decisions indicate that the defendant has the burden of pleading and proving his or her good faith. ${ }^{21}$

The good faith immunity test has both a subjective and an objective component, as the District Court correctly acknowledged in Rogers. The objective component asks, "When is the belief of the official in the legality of his acts unreasonable?" Three factors are relevant. First, was the constitutional right at issue clearly established at the time of the challenged conduct? (The District Court in Rogers noted that the right to refuse treatment was not developed as of 1973 and that case law supported a policy of involuntary medication. ${ }^{21}$ ) Second, did the official know (or should he have known) of the existence of the right? To answer this, the date of the change in the law is critical ${ }^{23}$ but not determinative, for if the change is foreseeable or already ordained, that may be sufficient to establish liability. A mistake as to the law is generally not a defense. ${ }^{24}$ Given the inconsistency in the opinions at the time the Rogers case was decided, the District Court was warranted in holding that a change in the law was not foreseeable at that time. Third, did the official know (or should he have known) that his conduct violated the norm? ${ }^{25}$ In Rogers, the answer to the first two questions again answers the third: regardless of the official conduct at issue, there was no preexisting norm against which to measure it.

The other, subjective, component of the good faith immunity defense asks, "Did the official act with 'malicious in tention' to deprive the petitioner of a constitutional right or to cause him other injury?"'26 Subjective bad faith may be proved by inferences from the circumstances, such as the failure of an official to obey existing procedural rules. ${ }^{27}$ In Rogers, the District Court listed several factors relevant to the determination of subjective good faith. The first factor is evidence of malice, defined as "callous or wanton neglect," or "reckless indifference." 28 The fact that a treating therapist felt he had the patient's best interests at heart would not per se be a sufficient defense. ${ }^{29}$ The relative helplessness or dependency of the plaintiffs might provide a basis for inferring malice. The second factor is evidence of improper purpose in medicating, such as punishment, vengeance, or sadism, or the predominance of these purposes over the valid purpose of helping or treating.

The objective and subjective components of the "good faith" tests are not two separate tests which must in all cases be satisfied. If the constitutional right is judicially established in a clear fashion, then the official's simple disregard of the right could well be malicious behavior.

In determining the validity of the good faith immunity defense in Rogers v. Okin, the District Court drew upon Wood v. Strickland, where the Supreme Court said that a goal of the immunity doctrine is to give administrators leeway to exercise discretion within the scope of their official duties. The Rogers court thus took into account the totality of circumstances at Boston State Hospital and held the good faith immunity defense to be valid: the state of the law was undeveloped, the right to refuse treatment had not been widely articulated, and the primary purpose of drug administration was treatment, not punishment. The court also noted the difficult conditions under which the defendants worked:

The facilities and support staff at Boston State were marginal, at best. In contrast, the patient population was extremely demand- 
ing, both in terms of numbers and their potential for disruptive behavior. Defendants did not have the luxury of detached, leisurely reflections as they faced the innumerable crises that characterized daily living on the Austin and May wards. They met those crises decisively, with the purpose of restoring plaintiffs to self control. ${ }^{30}$

Control of disruptive patients by de. fendants was a central issue for the District Court. The discrepancy between medicating to treat and medicating to control the level of disruption was one that the court resolved in favor of the defendants. " We will return to the issue of control versus treatment shortly.

\section{Damages: Their Uses and Limits}

Common law damages, as remedies for dignitary torts, fall into three groups: compensatory, nominal, and punitive. ${ }^{32}$ Compensatory damages aim to make the plaintiff "whole," that is, to undo the effects of the harmful act, while providing a deterrent to the defendant by shifting the cost of the plaintiff's injury onto him. Compensatory damages can be special or general. Special damages cover past pecuniary losses arising out of circumstances peculiar to the plaintiff's case; e.g., lost earnings, medical expenses, and property damage. ${ }^{33}$ They are recoverable only upon proof of actual loss. General damages include such items as the projected loss of income due to impairment of earning capacity, and intangible general damages such as mental suffering and distress.

The "dignitary" torts - battery, invasion of privacy, defamation - provide for an intermediate standard for proof of damages. In these torts, "the wrong is said to be damage in and of itself," ${ }^{34}$ and plaintiff has a reduced burden of proof as to the fact and amount of damage. General damages may be "presumed." That is, they may be imposed even in the absence of proof of any special damages to the plaintiff, and even where the plaintiff's interests cannot be precisely valued monetarily. ${ }^{35}$ Such presumed damages may constitute the sole element of recovery for the plaintiff, or may be tacked on to awards for special damages for such provable items as lost wages or medical expenses. ${ }^{36}$

Nominal damages are intended to vindicate the legal rights of the plaintiffs, and are usually set at a token level, $\$ 1$ or $\$ 10 .{ }^{37}$ Even if the plaintiff suffers no quantifiable harm, he has a right to rely on certain conduct from the defendant. An award of nominal damages for the violation of a constitutional right is simply a judicial recognition of the right, but it is a remedy without teeth.

Punitive damages are awarded to punish those engaged in egregious conduct and to deter such conduct in the future. ${ }^{38}$ In Carey, the Supreme Court acknowledged that punitive damages might be permitted "in a proper case under $\$ 1983$ with the specific purpose of deterring or punishing violations of constitutional rights. ${ }^{139}$ A punitive award might be appropriate where the defendant acted with malicious intent toward the plaintiffs.

In constitutional litigation, however, courts have on occasion awarded punitive damages in the absence of proof of actual damages.

The elements of malicious intent include a state of mind in which the actor desires the consequences of his action or believes that they are substantially certain to occur. ${ }^{40}$ However, a high degree of fault, such as evidence of morally reprehensible behavior, is usually required by the courts. The measure for punitive damages varies widely from court to court. Some courts require that the plaintiff prove actual damage before punitive damages can be awarded, ${ }^{41}$ or that the punitive damages bear some reasonable relationship to the amount of compensatory damages awarded. ${ }^{42}$ In constitutional litigation, however, courts have on occasion awarded punitive damages in the absence of proof of actual dam. ages, so long as the violation of a right has been established. ${ }^{43}$ Such damage awards have an important function in deterring official misconduct, especially where equitable relief is not forthcoming. ${ }^{44}$

The District Court in Rogers consid- ered the range of available damages only briefly as a prelude to its discussion of immunity. The court noted that damages might include compensation for

any physical or emotional harm caused thereby, as well as an award for all pecuniary loss.... In addition, exemplary or punitive damages may be awarded if the trier of fact is persuaded, by a preponderance of the evidence, that a defendant's action amounted to a demonstration of improper motive, outrageous conduct and overall bad faith. ${ }^{45}$

The full complexities of damages, their doctrinal and practical limits, were not discussed in full, because of the court's preliminary conclusion that a qualified official immunity applied. The Court of Appeals in Rogers, commenting on the damage question, simply noted that the District Court's findings of good faith were supported by the record. ${ }^{40}$

The denial of damages in Rogers is a closed issue, but another case may be decided differently. Now that the constitutional right has been articulated, thus making damages available, the answer may not be clear. Can a patientplaintiff now claim damages? What types? What likely effect will the imposition of monetary damages have upon institutional therapists and the institution itself?

\section{The Right-Remedy Link}

The right to refuse treatment, as we have seen, is based upon a concept of personal autonomy drawn from, and analogous to, the common law "dignitary" torts. Courts have developed principles to allow the plaintiff to recover a dollar amount even where actual injury is not provable, recognizing that deterrence and vindication of personal interests are as important as compensation in these actions. ${ }^{47}$ Likewise, in a Section 1983 action like that brought in Rogers, deterrence is a primary objective, "precisely the proposition upon which $\$ 1983$ was enacted." 48

In Carey, the Supreme Court began with the proposition that compensation for injuries, based on the analogous branch of tort law, should be the 
measure of damage. ${ }^{49}$ Most common law torts allow compensation for lost earnings, medical expenses, etc., as well as punitive damages, but do not allow damages for the loss of a right, even though it may be constitutionally protected, without consequent injury. ${ }^{\circ 0}$ Therefore, absent a showing of actual harm, plaintiffs alleging deprivation of constitutional rights have little chance of recovering anything but nominal damages. Carey was a procedural due process case, and its narrow view of proof of actual damages arguably applies only to such cases, and not to the violation of other substantive rights such as the Fourth Amendment. The Carey Court appeared to leave this possibility open.

Yet, a narrow reading of the spectrum of damage remedies available in right to refuse treatment cases leaves the plaintiff with little prospect of recovery, for several reasons. First, provable general damages may not exist. Second, special damages, like medical expenses, are also unlikely to exist in such cases, unless the patient in fact develops tardive dyskinesia or some other serious side effect. In Rogers, the benchmark for measuring harm to the plaintiffs was elusive. Plaintiffs presented no evidence that they suffered from tardive dyskinesia, the most severe and dramatic of the drug-related side effects. Since the medication does control symptoms which might otherwise be disruptive or damaging to the patient, a definition of physical harm is hard to apply. Additionally, a schizophrenic patient, given his psychological state, has special difficulties in trying to prove mental distress. Plaintiffs are therefore presented with prodigious problems of proof in such cases. Third, nominal damages, while requiring that the defendant recognize the plaintiff's right by means of the token payment, tend to trivialize it at the same time, since they fail to convey the heft to the right and its ranking on a hierarchy of values. Fourth, punitive damages suffer from two limitations: malice must be proved, and the punitive award must be reasonably related to the actual damages suffered. Given the judicial recognition in Rogers of the shortcomings of state funding and the disruptive nature of the patients, courts are unlikely to find the requisite level of malicious intent required for the imposition of punitive damages.

What is missing in the right to refuse treatment cases is the availability of presumed damages. While the Supreme Court in Carey explicitly fore-

What is missing in the right to refuse treatment cases is the availability of presumed dam. ages. Carey left open the possibility that presumed damages might be applied for violations of constitutional rights other than procedural due process.

closed such a damage remedy for procedural due process cases, it left open the possibility that where other constitutional rights are involved, like the First Amendment, presumed damages might be applied. ${ }^{51}$ It is not settled whether Carey applies to all constitutional violations or simply to procedural ones, and a strong argument can be made that presumed damages are a necessary component of relief for substantive constitutional violations, and should be available to a federal judge evaluating his or her remedial options in a right to refuse treatment case.

Increasing the Remedial Arsenal of the Courts: The Need for Damages

The function of a damage remedy, like that of equitable and structural remedies, is to alter behavior through judicially imposed devices. Thus, the District Court in Rogers considered a structural remedy of a judicially appointed guardian when a patient refused treatment. The Court of Appeals, finding such a mechanism to be "impractical and largely incapable of enforcement," 52 suggested a mechanism for "periodic review by non-treating physicians" of the treatment given to patients. In Rennie v. Klein, ${ }^{53}$ the federal District Court in New Jersey imposed an elaborate extra-judicial system in which patients had access to patient advocates and were assured that an informal review of their case by an independent psychiatrist would occur "before the hospital may forcibly medicate an involuntary patient." The choice of procedural measures relates to a judicial perception that such measures can effectively alter institu- tional behavior to decrease the intrusive medicating of patients. Such a presumption in favor of procedural barriers or external review of medication decisions may not, however, properly balance a patient's right to refuse treatment with necessary treat ment flexibility. Will such procedural remedies "give treating physicians too much control and arguably too little accountability?"55 Will such remedies prove futile, because of successful circumvention by staff? Or will the complexities they introduce affect professional morale and practice so adversely that treatment suffers? ${ }^{56}$ The argument in favor of equitable relief in constitutional tort cases is twofold: (1) it provides a clear and specific command to those in the institution, unlike damage remedies which create only generalized incentives toward change on the part of the institutional defendants; (2) since the relief is usually aimed at the institution, and at its procedures and structures, it seems fairer as well as potentially more effective than an award of da mages since it is often an institutional problem scarce resources, poorly managed staff-that is at issue, rather than the culpability of individual therapists. ${ }^{57}$

In contrast to equitable remedies, which impose procedural review mechanisms or guardian procedures, damages act indirectly. The assumption is that the imposition of monetary costs on an individual will lead him to reassess the effects that his actions have on others, pushing him toward a more acceptable personal calculation which accounts for the values inherent in the constitutional norm. ${ }^{58}$ A damage judgment represents both a condemnation of past conduct as not measuring up to acceptable levels of performance, and a warning of future costs if deviant conduct continues. Damage remedies have their own problems. First, the cost may simply be absorbed by malpractice insurance, so that the residual impact on therapist behavior is due only to marginal increases in malpractice premiums and to the psychic costs of being named a culpable defendant. Second, the utility of a damage remedy depends upon the ease with which a standard of desirable performance can be defined and departures from it identified. ${ }^{59}$ In right 
to refuse treatment cases, the refusal by a patient is easily ascertained, but it is difficult to determine in each instance whether the refusal is competent, and therefore whether the defendant engaged in culpable behavior. Third, the damage remedy may seem unfair, if we accept, as did the Rogers court, that environmental and financial limitations place the therapist in a difficult position in pursuing effective treatments. If the problem is perceived as purely an institutional one, then damages against the individual therapists are unfair (except as punishment for exceptionally malicious conduct) since the therapists do not bear responsibility for the problems. The federal courts have generally appeared uncomfortable with the damage remedy, insofar as it places responsibility on such individuals.

\section{Control versus Treatment}

In attempting to resolve the damageequitable relief dilemma, a proper understanding of the uses of psychotropic drugs may suggest a better and more balanced view of remedies. Psychotropic drugs, with their potential of bureaucratic control, allow the handling of admittedly difficult residents for the convenience of the administrators as well as for treatment of the individual inmates. One federal judge has noted that in one Pennsylvania state hospital "psychotropic drugs ... are often used for control and not for treatment, and the rate of drug use in some of the units is extraordinarily high." 60 Care is often "incompetent, callous and abusive." 61 Residents on drugs are compliant and easy to manage, and the drugs therefore reduce objectional behavior by reducing all behavior. Therapists may be unwilling in some cases to withdraw or reduce drugs, in spite of substantial and serious side effects, for fear of patient relapse. ${ }^{62}$ The risks are considered worth the achievement of patient control. ${ }^{63}$ Brooks has noted that side effects are often not even perceived by staff physicians. "In many hospitals, psychiatrists apparently do not perceive or acknowledge the gross physical manifestations of tardive dyskinesia. Nor are these physicians sensitive to other side effects reported by patients, such as extensive sleepiness, anxiety, agitation, and excessive motor activity." 64 Overcrowding, understaffing, and lack of supervisory controls create some need for the drugs, as a shortcut to supervision, rather than as an individualized approach to patient treatment. ${ }^{65}$ The drugs may mask symptoms, leading to incorrect diagnosis and treatment..$^{60}$ More important, their long-term use may lead to serious irreversible patient harm, as with tardive dyskinesia. In short, the benefits of the drugs may be overstated with seference to their overall effective. ness. ${ }^{67}$ There was evidence that in the New Jersey state hospitals medications were abused, and that by ignoring side effects or prescribing excessive amounts, psychiatrists retaliated against patients who refused drugs or protested their use. ${ }^{68}$ The prescribing therapists may also place excessive reliance on the drug manufacturer's literature for information and research findings, and may have no systematic follow-ups, safeguards, or awareness of hazards. ${ }^{69}$ Even within the psychiatric establishment, some doubt the wisdom of extensive use of these drugs, and advocate the use of alternative therapies until a fuller picture of both benefits and side effects has emerged. ${ }^{70}$ Some psychiatrists have contended that the primary effectiveness of psy. chotropic drugs is in controlling acute psychotic episodes in the young, rather than in treating the old, chronically mentally ill who typically occupy mental institutions. ${ }^{71}$

The uncertainties surrounding the use of psychotropic drugs for treatment are substantial. And, the abuse of such drugs for control rather than for treatment has been common in state institutions generally. The ultimate result of a constitutional right to refuse treatment, coupled with the correct arsenal of remedies, may be to press the therapists into monitoring their use of psychotropic drugs more closely, leading to a reduction in the use of such drugs and a greater use of less damaging alternatives. ${ }^{72}$

\section{Conclusion}

What balance of remedies can be suggested in light of the tension between control and treatment in the right to refuse treatment cases? A review procedure like that developed in Rennie $v$.
Klein allows a hard look at medication decisions on a case-by-case basis. This obviates the need for judicial intervention and for the appointment of guardians, which was the solution rejected by the Court of Appeals in Rogers. Minimal review procedures of a sort suggested by the Court of Appeals are worthy of consideration, although they ease the pressure on the therapist to monitor drug use closely in each case.

And damages? A doctrine of awarding presumed damages, imposed even though the patient is unable to prove actual physical injury other than general distress at having been medicated against his will, may better convey the relative status of the right at stake. Damages are a judicially imposed reminder that a staff therapist has responsibility for treatment and that, like any medical professional, he is expected to know his medications and their side effects, and to recognize those effects and terminate treatment when needed. A damage remedy is a concrete reminder, as a procedural mechanism may not be, that the therapist is ultimately responsible for the quality of the treatment he administers. A sensitivity to the need to make treatment, rather than control, the dominant objective suggests that a significant damage remedy must be available to deter careless, abusive or punitive medication decisions. Damages seem unjust only if we perceive that it is the institution that is defective. But if we are willing to look at treatment decisions closely, then damages may serve a valuable function as an addition to carefully designed supervisory or monitoring mechanisms.

\section{References}

1. Fiss, O.M., Foreu ord: The Forms of Justice, HaRvard Law Review 93(1): 1, 52 (November 1979).

2. Friendly, The Courts and Social Policy: Substance and Procedure, UNIVERSITY OF MIAMI LAW REVIEW 33:21 (1978).

3. E. Cassell, The Healer's Art (Lippincotc, Philadelphia) (1976) at 146-47:

Not only does sickness cause the patient to

lose control of the environment but, even more fundamentally, it causes him to lose control of his body. . . The body has become a dangerous, alien thing.

Thus, a mental patient, who has in some cases adjusted to his symptoms, is forced to confront the physical manifestations of the psychotropic drugs, many of which entail substantial loss of control of his body and its functions. 
4. See Gavison, Privacy and the Limits of the Lau. YALE LAW JOURNAL 89:421, 449 (1980). 5. Rogers v. Okin, 478 F. Supp. 1342 (D. Mass. 1979), 634 F.2d 650 (1st Cit. 1980), vacated sub nom. Mills y. Rogers, _ U.S.

(1982). After this article was written, the Supreme Court remanded the case to the First Circuit for a determination of whether a right to refuse treatment with psychotropic drugs ex. ists under Massachusetts law. The Court did not decide whether such a right exists in federal law, and therefore did nor reach the issue of damages.

6. Rogers v. Okin, 478 F. Supp. 1342, 1365 (D. Mass. 1979).

7. Id. quoting Superintendent of Belchertown State School v. Saikewicz, 370 N.E.2d 417, 426 (Mass. 1977).

8. Rogers v. Okin, 634 F.2d 650,653 (1st Cir. 1980)

9. Id.

10. See Stone, The Right to Refuse Treatment,

ARChives of General PsychiatRy 38(3): 358 (March 1981)

11. Carey v. Piphus, 435 U.S. 247 (1978)

(plaintiffs were high school srudents awarded nominal damages only, for deprivation of due process when they were su spended from school).

12. Id. at 254

13. Id. at 258

14. Id.

15. Id.

16. Id. at 259

17. Id. at 258

18. Id.

19. See, e.g. Halperin v. Kissinger, 606 F.2d 1192 (D.C. Cir. 1979) (denial of Fourth

Amendment rights through electronic surveil lance; proof of actual damages are not required because of the nature of the interests involved). 20. Wood v. Strickland, 420 U.S. 308, 318 (1974).

21. Gomezv. Toledo, 446 U.S. 635 (1980).

22. Rogers v. Okin, supra note 6 , at $1382-83$

23. See Nichols v. Layman, 506 F. Supp. 267

(N.D. Ill. 1980) (change in law on constitutional right to treatment).

24. Bailey v. Lally, 481 F. Supp. 203 (D. Md 1979) (unclearness of law on use of prisoners for medical experiments); Saffron v. Wilson, $481 \mathrm{~F}$. Supp. 228 (D. D.C. 1979) (lack of clarity of rules governing demonstration near the White House).

25. Wood v. Strickland, 420 U.S. 308, 322 (1974).

26. $1 d$

27. McCray v. Burrell, 622 F.2d 705 (4th Cir. 1980 ) (failure to notify psychologist about bizarre behavior of in mate after placing him in solitary).

28. Rogers v. Okin, supra note 6. at 1382.

29. Id. at 1382, quoting from Downs v. Saw-

telle, 574 F.2d 1, 12 (1st Cir. 1977), cert. denied. 439 U.S. 910 (1978)

30. Rogers v. Okin, supra note 6 , at 1383 . For a discussion of the effects of the litigation upon the operation of the Austin Unit at Boston City Hospital by the unit's director, see Gill, M.J., Side Effects of a Right to Refuse Treacment Law'suit in REFUSING TREATMENT IN MENTAL Health INSTItUTIONS-VAlues IN Conflict (A.E. Doudera, J.P. Swazey, eds.) (AUPHA. Ann Arbor) (1982).

31. "Like frontline surgeons, they were required to work with what they had. ... [I]t would be unjust and unreasonable for courts to hold psychiatrists personally and individually responsible for resource deficiencies that are actually the responsibility of society." Id. at 1385 .

32. D. DOBBS. HANDBOOK ON THE LaW OF REMEDIES $\$ \$ 3.1,7.3(1973)$ Ihereinafter cited as DOBBS].

33. Id.

34. Id. at $\$ 7.3$.

35. One court following Carey 2 . Piphus has allowed presumed damages in a case involving a prisoner incarcerated in a segregated jail. In Mickens v. Winston, 462 F. Supp. 910 (E.D. Va. 1978), aff'd mem. 609 F.2d 508 (4th Cir. 1979), the court concluded that "although plaintiff" has failed to vocalize, with any specificity, his alleged injury, confining his testimony to 'feel ing bad, 'by virtuc of defendant's intentional policy of racial segregation, the court concludes he was presumptively injured, for which he is entitled to a monetary award." 462 F. Supp. at 913.

36. Brooks v. Moss, 242 F. Supp. 531, 532 (W.D.S.C. 1965) (\$3,500 compensatory award for police assault includes element for "deprivation of rights as a citizen"). One comment ator has suggested that Congress set a fixed minimum recovery to effectuate the presumed dam. age remedy. See Note, Damage Aurards for Con. stitutional Torts: A Reconsiderarion after Carey v. Piphus, Harvard Law Review 93(5): 966,989 and n.141 (March 1980).

37. DOBBS, suira note 32 at $\$ 3.8$

38. Cochettiv. Desmond, 572 F.2d 102 (3rd Cir. 1978).

39. Carey v. Piphus, supra note 11 , at 257 n.11.

40. Restatement (Second) Torts, \$8 A (1965), defining "Intent: The word 'intent' is used to ... denote that the actor desires to cause the consequences of his act, or that he be lieves that the consequences are substantially certain to result from it. . . .'

41. See Fountila v. Carter, 571 F.2d 487 (9th Cir. 1978 ) ( $\$ 5.000$ punitive award based on $\$ 1$ actual injury overturned).

42. DOBBS, supra note 32 , at $\$ 2.9$

43. See e.g. Zarcone v. Perry, 572 F.2d 52

(2nd Cir. 1978); Silver v. Cormier, 529 F.2d

161, 163 (10th Cir. 1976); Spence v. Staras, 507

F.2d 554 (7th Cir. 1974); Basista v. Weir, 340

F.2d 74 (3rd Cir. 1965).

44. See Cochetti v. Desmond, supra note 38 at 105-06: "The availability of punitive damages as a deterrent may be more significant than ever today, in view of the apparent trend of decisions curtailing the powers of federal courts to impose equitable remedies to terminate such [constitutional] violations. "See genetally Love, J.C., Damages: A Remedy for the Violation of Constitutional Rights, CALIFORNIA LAW REVIEW $67(6): 1242,1275$, n.274 (a typical range of punitive damage awards, from $\$ 250$ to $\$ 10,000$, is set forth)

45. 478 F. Supp at 1381

46. 634 F.2d at 662

47. See Harper \& james, The Law of TORTS, vol. $1, \$ 5.30$ at $468-70$ (1956); Caperci v. Huntoon, 397 F.2d 799 (1st Cir.), cert. denied. 393 U.S. $940(1968)$

48. Imbler v. Pachtman, 424 U.S. 409, 442

(1976) (White, J., concurring).

49. Carey v. Piphus, supra note 11 , at 265 . See

S. NAHMOD, CNIL RIGHTS AND CIVIL LiBERTIES HANDBOOK $\$ 4.02$ at 96 (1979).

50. Note, Damage Au'ards for Constitutional Torts: A Reconsideration after Carey v. Piphus,

Harvard LaW REV'IEW 93(5): 966, 968 (March
1980).

51. Careyv. Piphus, supra note 11 , at 265.

52. Rogers v Okin supra note 8 , at 660 .

53. Renniev. Klein, 476 F. Supp. 1294 ,

1307-15 (D. N.J. 1979).

54. Id. at 1312

55. Mills, M.J., The Continuing Clinicolegal Conundrum of the Boston State Hospital Case, MEDICOLEGAL NEW 9(2): 9 (April 1981).

56. See Brooks, A., The Constitutional Right to Refuse Antipsychotic Medications, BLLLETIN OF THE AMERICAN ACADEMY OF PSICHIATRY \& THE LAW 8(2): 179 (1981).

57. See generally Whitman, C.. Constitutional Torts, MichiGaN Law REvIEW' 79(1): 5, 48-52 (1980).

58. For a discussion of "general detertence," see G. Calabresi, The COSTS If ACCidents

(Yale Univ, Press, New Haven) (1970) at

$135-97$.

59. Cass, R.A.. Damage Suits Against Publi: Officers, UNINERSITY OF PENNSTLIANIA LAW RE. VIEW 129(5): 1110,1139(1981)

60. Halderman 1'. Pennhurst State School \& Hospital, 446 F. Supp. 1295, 1307 (E.D. Pa. 1977).

61. Brooks, supra note 56 , at 189

62. See Caffrey, et al. Discontinuation or Re. duction of Chemotherapy in Chronic Schisophren ics, JOURNAL OF Chronic Disability 17(4): 347 (1964).

63. See Huth, Mind Medicine's Side Effects: Are the Risks Worth the Cure? Washington Post, April 9, 1972 at B-3, col. 1.

64. See Brooks, supra note 56 , at 188

65. The control of symproms may not even have a therapeutic purpose in some cases, since the symptomatic behaviors may be preferred by the patients to the sedative effects of the neuroleptic drugs. Van Putton, Crumpton, Yale,

Drug Refusal in Sthizophrenia and the Wish to be

Ctazy. ArChives of General Psychiatry

33(12): 1443 (December 1976).

66. Gaughan, LaRue, The Right of a Mental Patient to Refuse Antipsychotic Drugs in an Institu. tion, LAW AND PSYCHOLOGY REVIEW 4:43 (1978).

67. Marholin. Phillips, Methodological lssues in Psychopharmaceucical Research. AMERICAN JOURNAL OFORTHOPSYCHIATRY 46 3 ) 477 (July 1976)

68. See Brooks, supra note 56, and discussion in Rennie v. Klein, supra note 53.

69. Seg Group for the Advancement of Psychiatry publication, Pharmaco. Therapy and Psy chotherapy: Paradoxes, Problems and Progress, at 173.74(1975)

70. See Kle in, Who Should Not be Treated with Neuroleptics But Often Are, in Rational Psy. CHOPHARAIACOTHERAPY AND THE RIGHT TO TreatMent (F. Ayd, ed. 1974). See also Carpenter, McGlashan, Strauss, The Treatment of Schi:ophrenia without Drugs: An Intestigation of Some Current Assumptions. AMERICAN JOLRnAl of PsYCHIATRY 134(1): 14 (January 1977); Klawans, Goetz, Perlik, Tardive Drskinesia: Revieu and Update, AMERICAN JOURNAL OF PSYCHIATRY 137(8): 900 (August 1980).

71. Dr. Jonathan Cole, groted in Sobel Something Nasty at the Botzom of the Psychiatric Drug Bottle. New York Times. Junc 8, 1980, at 20F 72. See Brooks, supra note 56, at 202 (evidence that the level of use of the psychotropic drugs dropped of dramatically in the New Jer sey state hospitals after the Rennie decision). 